\title{
Comparison of fermentation results and quality of the agricultural distillates obtained by application of commercial amylolytic preparations and cereal malts
}

\author{
Maria Balcerek $^{1} \cdot$ Katarzyna Pielech-Przybylska $^{1} \cdot$ Ewelina Strąk $^{1} \cdot$ Piotr Patelski $^{1}$ • \\ Urszula Dziekońska ${ }^{1}$
}

Received: 8 June 2015 / Revised: 26 August 2015 / Accepted: 30 August 2015 / Published online: 14 September 2015

(C) The Author(s) 2015. This article is published with open access at Springerlink.com

\begin{abstract}
The objective of this study was to determine the efficiency of rye starch hydrolysis in mashing processes using either enzymatic preparations or cereal malts and their effect on the chemical composition of prepared mashes, fermentation results, as well as the composition of the obtained distillates. The raw materials used were unmalted rye grain and different malts (wheat, rye, and barley malts). The differences in the chemical composition of the distillery mashes, depending on the type and amount of malts used, were observed. The concentrations of reducing sugars were twice as high in mashes containing $30 \%$ cereal malts as in the reference sample prepared with enzymatic preparations $(56.2 \pm 1.8) \mathrm{g}$ glucose $\mathrm{L}^{-1}$ mash. An increase in the content of cereal malt in mashes from 30 to $50 \%$ did not significantly improve the initial degree of starch saccharification. The highest ethanol content $(8.40 \pm 0.25) \%$ vol. was found in the mash containing $50 \%$ rye malt, but the fermentation efficiency in this case was the lowest among all fermentation trials and reached only $(75.39 \pm 1.88) \%$ of the theoretical value. The highest efficiency of process $(87.92 \pm 2.19) \%$, comparable to that obtained from the rye mash digested with amylolytic preparations $(86.60 \pm 2.17) \%$, was found in the mash prepared with $50 \%$ wheat malt. The fermentation of mash containing $50 \%$ unmalted rye grain and $50 \%$ barley malt gave the lowest ethanol concentration $(6.60 \pm 0.12) \%$ vol. in the mash after fermentation. The distillates originating from mashes containing cereal malts were characterized by
\end{abstract}

Maria Balcerek

maria.balcerek@p.lodz.pl

1 Department of Spirit and Yeast Technology, Institute of Fermentation Technology and Microbiology, Lodz University of Technology, Wolczanska 171/173, 90-924 Lodz, Poland lower concentrations of undesirable acetaldehyde than the distillate obtained from unmalted rye alone.

Keywords Starch · Hydrolysis - Cereal malt · Rye · Agricultural distillate

\section{Introduction}

Cereals are extensively used to produce alcoholic beverages, such as beer, vodka, whisk(e)y, bourbon, and others. Alcoholic beverages made from fermented grain mashes are widespread and highly respected around the world for their flavor and taste. The most frequently consumed alcoholic beverage in the world is beer [1]. The use of cereals as raw materials by the brewing industry can be divided into two main categories: malt and adjuncts. Also, many distilled beverages are produced from malt because of flavor enhancement [2].

Barley (Hordeum vulgare, vulgare L.) is the primary cereal used in the production of malt in the world. Two types of barley are frequently used for the malting process: 2-row and 6-row. Two-row barley produces malt with a large extract, lighter color, and less enzyme content than the 6-row type [3].

In many countries, the production of barley malt-based spirits, such as Scotch whisky and Irish whisky, has a centuries-old tradition and constitutes an important sector of the economy. Generally, they differ in terms of the type and proportion of the cereals used as raw materials and in terms of the type of stills used in the distillation process. The principal types of whisky also differ by geographical region. A characteristic feature of Scotch malt whisky is that the only cereal used in its manufacture is malted barley. It is the most commonly malted grain, in part because 
of its high diastatic power, or enzyme content, though wheat and rye are also used $[4,5]$. In the production of Scotch whisky, malted barley is used as a source of both $\alpha-$ and $\beta$-amylase. After milling, the grist is mashed in a tun. During mashing, the enzymes present in the cereal malt catalyze the hydrolysis of starch into fermentable sugars (especially maltose) $[6,7]$. The production of malt whisky shares many parallels to the production of an all-malt beer. The fundamental difference between distilling and brewing production practices is that Scotch whisky distillers do not boil their worts, since they need to retain the maximum levels of endogenous enzyme activity into the fermentation process to ensure that as much of the starch as possible is hydrolyzed to fermentable sugars, which can be converted efficiently into alcohol by yeast [8].

In the manufacture of Scotch grain whisky, other cereals are used along with malted barley to supply additional starch in the mash tun [5, 9]. For many years, maize was the traditional grain for Scotch grain whisky production, until it was effectively replaced by wheat, primarily because of its more favorable economics [10, 11]. Assessment of wheat varieties by the distilling industry and dialogue with plant breeders has led to obtain improved varieties from which distillers are capable to produce alcohol with yields equivalent to those obtainable from maize $[12,13]$. Despite the fact that wheat has successfully replaced maize, there are still some concerns regarding difficulties with handling this cereal in the distillery. These result from the higher viscosity, associated with wheat, which can affect the efficient handling of stream process (cooking and mashing). Therefore, maize is still considered to be superior to wheat as it produces higher alcohol yields and presents fewer processing problems.

Cereals such as sorghum and millet are considered to have similar characteristics to maize and can be considered to use in the brewing process [14]. Sorghum is used as malted and distilled beverages in Africa and Asia [15, 16].

Europe's spirit drinks industry is the largest in the world. The main raw materials used by the EU spirit drinks industry are the agricultural products (cereals, potatoes, sugarcane, sugar beets, and wine) used to make the different kinds of spirits, and $85 \%$ of them is based on grain [17].

Value of production of agricultural products, among other spirits, is protected by a geographical indication (GI). Scotch whisky, Korn, and Polish Vodka are examples of EU geographical indications with an international reputation linked to the geographical area where they are produced [18]. Korn or Kornbrand is one of the interesting grain spirits produced in Germany, Austria, and Belgium (German-speaking community) [18]. According to the German Purity Law of 1909, Korn may only be produced using whole grain rye, wheat, barley, buckwheat, or oat, grown on German-speaking land. Korn differs from vodka as it is distilled to lower alcoholic proofs and less rigorously filtered, which leaves more of the cereal taste in the finished spirit. Traditional Korn contains at least $32 \%$ of alcohol by volume (ABV), while Doppelkorn or Edelkorn must contain at least $37.5 \%$ ABV [19].

Rye (Secale cereale) has been cultivated in Europe since ancient times and is genetically related to wheat and barley. Representing $<1 \%$ of the world cereal production, rye is mainly grown where rye breads are most popular, i.e., in countries such as Poland, Germany, and Western Russia. The rye grain is second after wheat in importance for the production of breads, and it is also important in the distillation of rye whisky and as livestock feeds [20].

Poland and Lithuania have a tradition of making Starka from aged raw rye spirits, which dates back to the late sixteenth and early seventeenth centuries. The basic raw material in the production of Starka is rye distillate (raw spirit) of suitable organoleptic properties and alcoholic strength by volume (ASV) of 91-92\%. A meaningful element of the assessment of the usefulness of a rye distillate for the production of this spirit is the determination of higher alcohols, whose desirable content is estimated at approximately $2 \mathrm{~g} \mathrm{~L}^{-1} 100 \%$ vol. alcohol, but raw spirits with their content of 3-3.5 $\mathrm{g} \mathrm{L}^{-1} 100 \%$ vol. alcohol also often provide good results. In fact, the results depend on the relative proportions of the various alcohols, i.e., n-propyl, isobutyl, isoamyl, and other alcohols, which often occur in very small amounts, but nevertheless influence the organoleptic properties of matured distillate [21].

Due to the importance of the spirits industry for consumers, producers, and the agricultural sector [22], technological innovation should be applied both to improve the quality of traditional spirits and to create new original spirit drinks. Also taking into account that there is an increase in amount of micro-distilleries worldwide, which gave better care and attention to craft or niche products [23], the production of spirits from malted and unmalted cereals may be incorporated in the manufacturing portfolio of small distilleries to bolster their competitiveness and facilitate attracting new customers interested in nonstandard distillates. The development of production technology of new kinds of distillates contributes to expanding the range of products and increases the production capacity of Polish distilleries.

The objective of this study was to determine the efficiency of rye starch hydrolysis in mashing processes using either enzymatic preparations or cereal malts as a source of amylolytic enzymes and starch and their effect on the physicochemical composition of the prepared mashes, fermentation results, and the composition of the obtained distillates.

The scope of this study included:

- physicochemical analysis of raw materials;

- preparation of sweet mashes by pressureless liberation of starch (PLS); 
- establishing the impact of the source of amylolytic enzymes (enzymatic preparations or cereal malts) on the efficiency of starch hydrolysis, chemical composition of sweet mashes, and efficiency of the fermentation process;

- analysis of mashes upon completing fermentation including the determination of apparent and real extract, reducing sugars, dextrins, and ethanol content;

- evaluation of ethanolic fermentation efficiency and the concentration of by-products in the distillates.

\section{Materials and methods}

\section{Raw materials}

Rye grain of the cultivar Dańkowskie Diament ("DANKO" Plant Breeding Ltd., Choryń, Poland) was used as the main raw material. Pale malt from wheat, pale malt from rye, and brown malt from barley (WEYERMAN ${ }^{\circledR}$ MALT, Germany) were also used, being a source of starch and amylolytic enzymes. They are recommended for the production of whisky, schnapps, and aromatic spirits [24].

\section{Enzymatic preparations}

The amylolytic preparations used were Termamyl SC ( $\alpha$-amylase from Bacillus stearothermophilus, EC 3.2.1.1) and SAN Extra (glucan 1,4- $\alpha$-glucosidase from Aspergillus niger, EC 3.2.1.3), purchased from Novozymes A/S (Denmark).

\section{Production of sweet mashes}

Distillery mashes were prepared from rye grain and cereal malts in a vessel placed in a water bath and equipped with a laboratory stirrer and thermometer by two methods.

With enzymatic preparations by pressureless liberation of starch (PLS) [25]

Milled rye grain $(1 \mathrm{~kg})$ was mixed with water heated to $50{ }^{\circ} \mathrm{C}$ (at a ratio of $3.5 \mathrm{~L}$ water per $1 \mathrm{~kg}$ of raw material) and the liquefying preparation Termamyl SC ( $\alpha$-amylase) was added $(0.13 \mathrm{~mL}$ per $1 \mathrm{~kg}$ of starch). This mixture was continually stirred and heated to $90{ }^{\circ} \mathrm{C}$. The medium was kept at this temperature for $30 \mathrm{~min}$, then cooled to approximately $60{ }^{\circ} \mathrm{C}$, and digested with the saccharifying preparation SAN Extra containing glucoamylase $(0.6 \mathrm{~mL}$ per $1 \mathrm{~kg}$ starch). Subsequently, the obtained sweet mash was cooled to a temperature at which fermentation was started $\left(30{ }^{\circ} \mathrm{C}\right)$. Before inoculation with yeast, the $\mathrm{pH}$ of the mash was adjusted from 5.5 (during mashing) to 4.5 using sulfuric acid solution $\left(250 \mathrm{~g} \mathrm{~kg}^{-1}\right)$. Mash was supplemented with an aqueous solution of $\left(\mathrm{NH}_{4}\right)_{2} \mathrm{HPO}_{4}\left(0.2 \mathrm{~g} \mathrm{~L}^{-1}\right.$ mash $)$ as a nitrogen source for yeast.

\section{With cereal malts}

Milled rye grain was mixed with milled cereal malts at a ratio of:

(I) $70 \%$ unmalted rye $+30 \%$ cereal malt;

(II) $50 \%$ unmalted rye $+50 \%$ cereal malt.

Then, the ground grain was mixed with fresh warm (approximately $40{ }^{\circ} \mathrm{C}$ ) water at the same ratio as the mashes prepared with amylolytic preparations and continually stirred and heated to $58-60{ }^{\circ} \mathrm{C}$. The mixture was kept at this temperature for $60 \mathrm{~min}$, and then, obtained sweet mash was cooled to $30{ }^{\circ} \mathrm{C}$. As in the case of mash prepared using enzymatic preparations, before inoculation with yeast, the $\mathrm{pH}$ of mashes was adjusted from 5.3 to 5.5 (during mashing) to 4.5 using sulfuric acid solution $\left(250 \mathrm{~g} \mathrm{~kg}^{-1}\right)$, and mashes were supplemented with an aqueous solution of $\left(\mathrm{NH}_{4}\right)_{2} \mathrm{HPO}_{4}\left(0.2 \mathrm{~g} \mathrm{~L}^{-1}\right.$ mash $)$.

\section{Yeast slurry preparation}

Fermentations were carried out using a preparation of Ethanol Red dry distillery yeast (S. cerevisiae) (Fermentis, Division of S.I. Lesaffre, France), designed for the production of alcohol up to $18 \%$ vol. at high temperature $\left(35^{\circ} \mathrm{C}\right)$. The number of living yeast cells at packing was $>2.0 \times 10^{10}$ per g, as declared by the manufacturer. Prior to inoculation of mashes, yeast was hydrated and disinfected (15min incubation of cells suspended in sulfuric acid solution, $\mathrm{pH} 2.5$, at room temperature) to eliminate weaker yeast cells and undesirable bacterial cells. The yeast slurry was added to the mashes at a ratio of $0.3 \mathrm{~g} \mathrm{~d}$.m. of yeast $\mathrm{L}^{-1}$ mash. The inoculated mashes were carefully mixed prior to fermentation.

\section{Fermentation of mashes}

Alcoholic fermentation of mashes was carried out in 10-L flat-bottomed flasks, each containing $6 \mathrm{~L}$ of inoculated mash. The flasks were closed with stoppers, equipped with fermentation pipes filled with glycerol, and kept in a thermostated room at $35{ }^{\circ} \mathrm{C}$ for $72 \mathrm{~h}$. After fermentation, samples were taken for quantification of ethanol concentration, apparent extract (extract of mash containing ethanol), real extract (after ethanol distillation), reducing sugars, and dextrins. 


\section{Distillation}

After the completion of fermentation, all ethanol was distilled from the mashes using a laboratory distillation unit consisting of a distillation flask, a Liebig cooler, a flask for collecting ethanol and a thermometer. Distillates containing from 20 to $23 \%$ of ethanol by volume were refined up to $\mathrm{ABV}(43 \pm 1) \%$ in a distillation apparatus equipped with a bi-rectifier unit (dephlegmator according to Golodetz) and subjected to chemical analysis.

\section{Analytical methods}

Raw materials, i.e., unmalted rye and cereal malts, were analyzed by the methods recommended for the agricultural and food industry for moisture content [26], reducing sugars [27], starch [28] as well as total nitrogen [26], calculated as crude protein (Nx6.25 for barley malt, Nx5.7 for unmalted rye, rye malt, and wheat malt) and expressed in percentage of dry weight.

The enzyme activities of cereal malts were measured using Megazyme kits (Megazyme Ltd, Bray, Ireland) according to the ICC standard methods [29]. $\alpha$-Amylase and $\beta$-amylase activities were measured using the Ceralpha method (kit K-CERA 01/12) and Betamyl-3 method (kit K-BETA3 10/10), respectively. All analyses for enzymatic activity were done in triplicate.

One unit of $\alpha$-amylase activity is defined as the amount of enzyme, in the presence of excess thermostable $\alpha$-glucosidase, required to release one micromole of p-nitrophenol (in the presence of excess quantities of $\alpha$-glucosidase) from non-reducing-end-blocked p-nitrophenyl maltoheptaoside (BPNPG7) in $1 \mathrm{~min}$ at $40{ }^{\circ} \mathrm{C}$. Activity is termed a Ceralpha unit [30].

One unit of $\beta$-amylase activity is defined as the amount of enzyme, in the presence of excess thermostable $\beta$-glucosidase, required to release one micromole of $p$-nitrophenol from $p$-nitrophenyl- $\beta$-D-maltotrioside (PNP $\beta-G 3)$ in 1 min at $40{ }^{\circ} \mathrm{C}$. Activity is termed a Betamyl- $3^{\circledR}$ unit [31].

Distillery mashes were analyzed according to the methods used in distilleries. In sweet mashes, total extract was measured using a hydrometer indicating the concentration of dissolved solids, mostly sugars, calibrated in $\mathrm{g}$ of sucrose or maltose per $\mathrm{kg}$ of aqueous solution $\left(\mathrm{g} \mathrm{kg}^{-1}\right)$ [26]. Other measurements included the determination of reducing sugars and total sugars after acid hydrolysis [27], as well as dextrins calculated as the difference between total sugars and reducing sugars taking into consideration the coefficient of conversion into dextrins (0.9), also expressed in $\mathrm{g} \mathrm{L}^{-1}$ mash. Upon the completion of fermentation, filtered mashes were analyzed for apparent extract (extract of mash containing ethanol) and real extract (after ethanol distillation), both measured using the same method as for total extract determination and expressed in $\mathrm{g} \mathrm{kg}^{-1}$ mash [26]. Furthermore, ethanol concentration was determined using an areometer scaled in percent of ethanol by volume [26] and the concentration of residual sugars, expressed in g glucose $\mathrm{L}^{-1}$ mash [27].

Chromatographic analysis of volatile compounds in the obtained distillates was carried out using a GC apparatus (Agilent 7890A, USA) with mass spectrometer (Agilent MSD 5975C, USA). A HP-5 MS capillary column (30 m length, $0.25 \mu \mathrm{m}$ film thickness, and $0.25 \mathrm{~mm}$ i.d.) was used to separate compounds. The GC oven temperature was programmed from 30 to $60{ }^{\circ} \mathrm{C}$ at a rate of $2{ }^{\circ} \mathrm{C} \mathrm{min}-1$ and then increased to $220{ }^{\circ} \mathrm{C}$ at a rate of $10{ }^{\circ} \mathrm{C} \mathrm{min}^{-1}$ (hold time: $5 \mathrm{~min}$ ). The flow rate of the carrier gas (helium) through the column was $1.1 \mathrm{~mL} \mathrm{~min}^{-1}$. The temperature of injector (split/splitless) was kept at $250{ }^{\circ} \mathrm{C}$. Injections $(1 \mu \mathrm{l})$ were made in the split mode (1:40). MS conditions were as follows: ion source temperature $230{ }^{\circ} \mathrm{C}$; transfer line temperature $250{ }^{\circ} \mathrm{C}$; quadrupole temperature $150{ }^{\circ} \mathrm{C}$; the ionization energy $70 \mathrm{eV}$. The mass spectra identification of the compounds was carried out by comparison with the MS spectra of computer library NIST 98.1 and the Wiley Registry of Mass Spectral Data, 8th edition. Qualitative analysis was verified by comparing the retention indices and mass spectra of identified compounds with those of authentic reference substance. For quantitative analysis, the MSD was operated in the selected ion monitoring mode (SIM). Quantitative analysis was performed using software Agilent MassHunter (USA). Gas chromatography standards were purchased from Sigma-Aldrich (St Louis, MO, USA) and were all of GC purity. Standard solutions were prepared using anhydrous ethanol (Sigma-Aldrich) as a solvent and refrigerated at $4{ }^{\circ} \mathrm{C}$ during storage.

\section{Evaluation of fermentation}

The intake of total sugars (the percentage of sugar consumption during fermentation) was calculated as the ratio of sugars used during fermentation to their initial content in the mash and expressed as a percentage. Fermentation efficiency was calculated according to the stoichiometric Gay-Lussac equation in relation to total sugars and expressed as a percentage (\%) of the theoretical amount, and fermentation yield was expressed as the volume of absolute ethanol $\left(\mathrm{A}_{100}\right)$ obtained from $100 \mathrm{~kg}$ of starch ( $\mathrm{L}$ of $\mathrm{A}_{100} 100 \mathrm{~kg}^{-1}$ starch) [21].

\section{Statistical analysis}

All fermentation samples were prepared and analyzed in triplicate. The results were tested statistically by analysis of variance (ANOVA) at a significance level $p \leq 0.05$ using Origin 7.5 software. 


\section{Results and discussion}

\section{The chemical composition of raw materials}

The varietal characteristics, the course of the growing season, agrotechnics, and the conditions of malting process are the key factors determining the quality of the cereals and the malts produced from them [32-36].

The chemical composition of the tested raw materials (Table 1) shows that the moisture content in the tested raw materials amounted $(88.0 \pm 3.56) \mathrm{g} \mathrm{kg}^{-1}$ unmalted rye grain, whereas in cereal malts was between $(35.0 \pm 1.85)$ $\mathrm{g} \mathrm{kg}^{-1}$ barley malt and $(50.0 \pm 2.85) \mathrm{g} \mathrm{kg}^{-1}$ wheat malt. Water content provides an indicator of the storability of cereals. Its content in malts should usually be below $5 \%$ [37].

The main criterion for the selection of raw materials for efficient ethanol production is sugar content. As a distillers' raw material, cereal grain is valued for its high efficiency because it is rich in starch [38]. The starch content in the used in our study rye grains Dańkowskie Złote cv. was at the level of $(621.0 \pm 15.4) \mathrm{g} \mathrm{kg}^{-1}$, which is consistent with data published in the literature [25]. In turn, the starch content in cereal malts was lower and ranged from $(505.0 \pm 13.6) \mathrm{g} \mathrm{kg}^{-1}$ wheat malt to $(542.7 \pm 15.5)$ $\mathrm{g} \mathrm{kg}^{-1}$ rye malt. The reason for the lower concentrations of starch after malting is due to the development of enzymes hydrolyzing the starch to soluble sugars [39, 40]. As a consequence, the obtained results show a significant difference between the amount of reducing sugars contained in unmalted rye and cereal malts. In unmalted rye grain (Dańkowskie Diament cv.), reducing sugars content amounted to $(14.7 \pm 0.6) \mathrm{g} \mathrm{kg}^{-1}$, whereas cereal malts contained significantly higher concentrations of these sugars, ranging between $(165.7 \pm 13.0) \mathrm{g} \mathrm{kg}^{-1}$ barley malt and $(188.9 \pm 18.9) \mathrm{g} \mathrm{kg}^{-1}$ wheat malt.

As regards protein content, it was higher in unmalted rye than in rye malt or others malts. This is due, among others, to the fact that some proteins are used during the controlled germination of cereals in the malting process [41]. Proteins are essential for the quality of malt. First, high protein content decreases available carbohydrates, adversely influencing the fermentation process, and second, proteolysis (protease hydrolysis producing amino acids and peptides) during malting and mashing is necessary for yeast metabolism [42, 43]. Yeast growth requires the uptake of nitrogen for the synthesis of protein and other nitrogenous components of the cell, but yeasts can only utilize low molecular weight nitrogenous materials such as inorganic ammonium ion, urea, amino acids and small peptides. The yeast cannot take up proteins or break down peptides larger than tripeptides [44]. As an essential nutrient, free amino nitrogen (FAN) is especially important for yeast growth in the beginning of the fermentation process [45]. The extracellular proteolytic activity of yeast is negligible. Proteolysis does not occur in the fermentation, unless the yeast has autolyzed. Nitrogen uptake slows or ceases later in the fermentation as yeast multiplication stops. When the sugar content is high and vital nutrients are lacking, a stuck fermentation can occur $[46,47]$.

Considering the above-mentioned aspects, to ensure appropriate conditions for the yeast fermentation activity, and to limit the development of bacterial infections, mashes were supplemented with ammonium ion, supplied as phosphate salt $\left(\mathrm{NH}_{4}\right)_{2} \mathrm{HPO}_{4}$.

As regards the amylolytic enzymes activities in used raw materials, it was found that unmalted rye (Dańkowskie Diament $\mathrm{cv}$.) was characterized by a low activity of $\alpha$-amylase $(0.83 \pm 0.007) \mathrm{CU} \mathrm{g}^{-1}$ and a significantly higher $\beta$-amylase activity at the level of $(4.96 \pm 0.38) \mathrm{BU} \mathrm{g}^{-1}$. Among the malts used in this study, the highest amylolytic activity showed the wheat malt, while the lowest was observed in the barley malt. This is consistent with the manufacturer's declaration, concerning the diastatic power of the tested malts expressed in Windisch-Kolbach units [24].

Table 1 Chemical composition of raw materials

\begin{tabular}{|c|c|c|c|c|}
\hline \multirow[t]{2}{*}{ Components } & \multicolumn{4}{|l|}{ Raw material } \\
\hline & Unmalted rye (Dańkowskie Diament cv.) & Wheat malt & Rye malt & Barley malt \\
\hline Moisture $\left(\mathrm{g} \mathrm{kg}^{-1}\right)$ & $88.0 \mathrm{a} \pm 3.56$ & $50.0 \mathrm{~b} \pm 2.85$ & $37.0 \mathrm{c} \pm 1.95$ & $35.0 \mathrm{c} \pm 1.85$ \\
\hline Starch $\left(\mathrm{g} \mathrm{kg}^{-1}\right)$ & $621.0 \mathrm{c} \pm 15.4$ & $505.0 \mathrm{a} \pm 13.6$ & $542.7 \mathrm{~b} \pm 15.5$ & $529.2 \mathrm{ab} \pm 13.4$ \\
\hline Reducing sugars $\left(\mathrm{g} \mathrm{kg}^{-1}\right)$ & $14.7 \mathrm{a} \pm 0.6$ & $188.9 b \pm 18.9$ & $176.1 \mathrm{~b} \pm 13.5$ & $165.7 \mathrm{~b} \pm 13.0$ \\
\hline Protein $\left(\mathrm{g} \mathrm{kg}^{-1}\right.$ s.s. $)$ & $103.5 b \pm 6.5$ & $100.5 b \pm 5.0$ & $84.5 \mathrm{a} \pm 3.2$ & $93.8 \mathrm{~b} \pm 4.2$ \\
\hline \multicolumn{5}{|l|}{ Amylolytic activities } \\
\hline$\alpha$-Amylase $\left(\mathrm{CU} \mathrm{g}^{-1}\right)$ & $0.83 a \pm 0.007$ & $350.45 \mathrm{~b} \pm 2.35$ & $266.09 \mathrm{~d} \pm 5.42$ & $149.83 \mathrm{c} \pm 1.82$ \\
\hline$\beta$-Amylase $\left(\mathrm{BU} \mathrm{g}^{-1}\right)$ & $4.96 \mathrm{~b} \pm 0.38$ & $95.55 \mathrm{~d} \pm 0.61$ & $86.14 \mathrm{c} \pm 0.56$ & $30.68 \mathrm{a} \pm 0.58$ \\
\hline
\end{tabular}

Results expressed as mean values $\pm \operatorname{SE}(n=3)$; values with different letters in the same line are significantly different $(p<0.05)$ 


\section{The chemical composition of mashes before and after fermentation}

The reference mash was prepared from unmalted rye grain with application of amylolytic preparations. Digestion with the enzymes contained the preparations was conducted sequentially. After the liquefaction of starch by bacterial $\alpha$-amylase (preparation Termamyl SC) in the time of $30 \mathrm{~min}$, subsequent stages of the process were conducted according to the principles of SSF process, i.e., the mash was cooled to approximately $60{ }^{\circ} \mathrm{C}$, supplemented with the saccharifying glucoamylase (preparation SAN Extra) and immediately cooled to the temperature at which fermentation was started $\left(30^{\circ} \mathrm{C}\right)$. Due to the procedure used, prepared rye mash was characterized by a higher content of dextrins $(64.9 \pm 2.5) \mathrm{g} \mathrm{L}^{-1}$ than reducing sugars $(56.2 \pm 1.8) \mathrm{g} \mathrm{L}^{-1}$. The principal benefits of performing the saccharification together with the fermentation are the reduced end-product inhibition of the enzymatic hydrolysis, and the reduced investment costs [48] should also be remembered that the saccharification stage is ideally suited for growth of very heat tolerant Lactobacillus strains known to create the lactic acid in fuel alcohol plants that interferes with yeast metabolism. Simultaneous saccharification and fermentation (SSF) technologies were developed for batch fermentation to eliminate bacterial contaminations and the resultant loss of ethanol yields [49].

Hydrolysis of starch to the fermentable carbohydrates glucose, maltose, and maltotriose is an important aspect of brewing as well as of distilling technology. Starch hydrolysis is carried out by the malt enzymes $\alpha$-amylase, $\beta$-amylase, limit dextrinase, and $\alpha$-glucosidase [50]. Because the activity of the different enzymes is highly dependent on temperature, the manipulation of such variable is the main control mechanism for the mashing process. The mashing in brewing technology often consists of several temperature steps, each favoring different malt enzyme activities. The lowest temperature $\left(45-50{ }^{\circ} \mathrm{C}\right)$ is the optimal temperature for cell wall degrading enzymes, $\beta$-glucanases, while the proteases works best at $52{ }^{\circ} \mathrm{C}$, the $\beta$-amylase at $60-65{ }^{\circ} \mathrm{C}$, and the $\alpha$-amylase at $72{ }^{\circ} \mathrm{C}$. The last step in the mashing is inactivation of the enzymes at $78{ }^{\circ} \mathrm{C}$. Two major starch-digesting enzymes are released from malt, $\alpha$-amylase and $\beta$-amylase. Temperatures of $60-65^{\circ} \mathrm{C}$ maximize the activity of $\beta$-amylase, while temperature $72{ }^{\circ} \mathrm{C}$ is optimal to $\alpha$-amylase activity [51, 52].

An energy-saving and brewing cycle time reducing solution is a simple heated step mashing at $60^{\circ} \mathrm{C}$ [53]. Analogously, the distillery mashes with the application of cereal malts were prepared.

The differences in the chemical composition of the prepared distillery mashes, depending on the type and amount of malts used, were observed (Table 2). The presence of wheat and barley malts (30 or $50 \%$ ) in sweet mashes did not significantly change their total extract content relative to the reference mash originating from unmalted rye alone $(p>0.05)$. Higher extract values between $(200.0 \pm 5.6)$ $\mathrm{g} \mathrm{kg}^{-1}$ and $(266.6 \pm 6.6) \mathrm{g} \mathrm{kg}^{-1}$ were observed in the mashes containing 30 or $50 \%$ rye malt. The obtained results stay in accordance with the ones described by Hübner et al. [45] who stated that the extract contents in rye malt-based worts are significantly higher than in barley malt-based worts, because rye lucks the husk which represent about $10 \%$ of barley dry weight.

The content of total sugars (after acid hydrolysis) in the mash obtained from unmalted rye was $(128.3 \pm 4.5)$ g glucose $\mathrm{L}^{-1}$ mash, while in mashes containing rye malt it ranged from $(155.0 \pm 5.5) \mathrm{g}$ glucose $\mathrm{L}^{-1}$ mash $(30 \%$ rye malt) to $(172.0 \pm 5.8) \mathrm{g}$ glucose $\mathrm{L}^{-1}$ mash $(50 \%$ rye malt). The concentrations of reducing (fermentable) sugars were twice as high in mashes containing $30 \%$ cereal malts as in the reference sample. An increase in the content of cereal malt in mashes from 30 to $50 \%$ did not improve significantly the initial degree of starch saccharification $(p>0.05)$. That led to a higher concentration of dextrins, especially in mashes containing rye malt despite the relatively high activity of amylolytic enzymes in this malt. It was probably that the amylolytic enzyme activities could be inhibited by high sugar content.

The chemical analysis of mashes after fermentation consisted of the determination of apparent and real extract, as well as the concentration of ethanol, reducing sugars, total sugars (after acid hydrolysis), and dextrins (Table 2).

During Scotch whisky production, the fermentation process is usually allowed to proceed to a point at which the specific gravity of fermented mash drops to below 1.0 [9]. Apparent extract (measured in the presence of ethanol which decreases medium density) for well-fermented distillery mashes with an initial extract of approximately $180 \mathrm{~g} \mathrm{~kg}^{-1}$ should not exceed $10-15 \mathrm{~g} \mathrm{~kg}^{-1}$ [54].

After 72-h fermentation, the tested mashes were characterized by higher values of apparent extract. In the mash originating from unmalted rye, it amounted $(18.5 \pm 0.5)$ $\mathrm{g} \mathrm{kg}^{-1}$, whereas in samples of mashes with $30 \%$ cereal malt it ranged from $(19.2 \pm 1.0)$ to $(28.0 \pm 1.2) \mathrm{g} \mathrm{kg}^{-1}$. Samples containing $50 \%$ malt were characterized by an apparent extract in the range of $(22.0 \pm 0.9)$ to $(26.0 \pm 1.3)$ $\mathrm{g} \mathrm{kg}^{-1}$.

In brewing technology, the suitability of the extracted compounds for ethanol production is reflected by the parameter called fermentability. This factor is defined as the percentage of extracted compounds, which can be fermented into ethanol by yeast. The fermentability values measured in rye malts ranged from approximately 73 to $77 \%$ [45] and are considerably lower than in barley malt (typically $>80 \%$ ) or wheat malt $(>78 \%$ ) [55]. This 


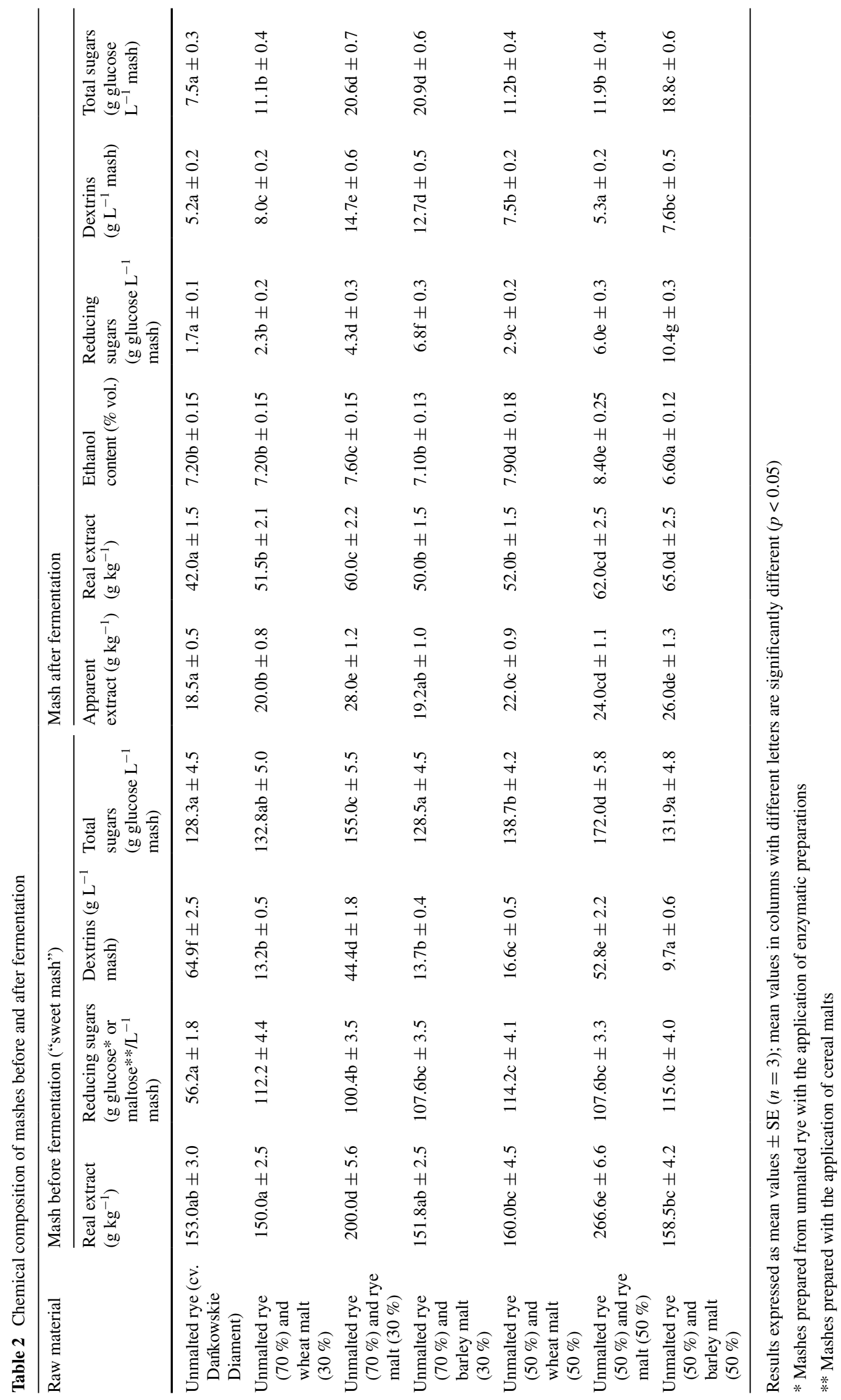




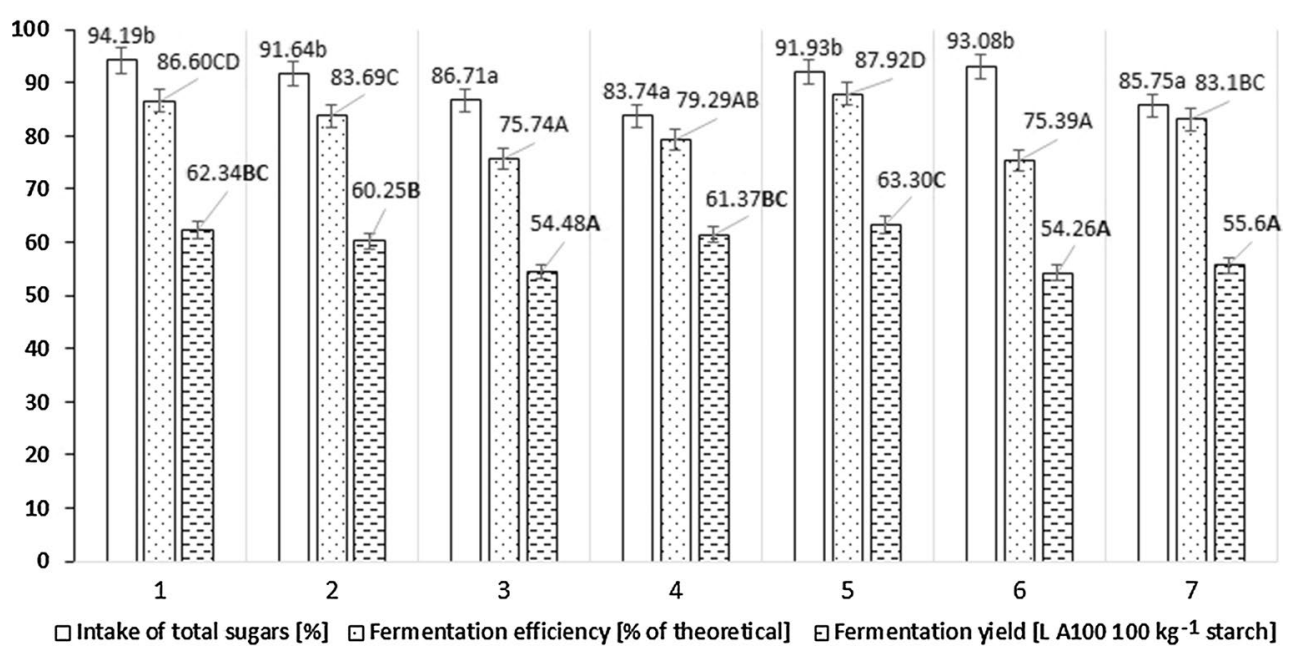

Fig. 1 Fermentation factors of mashes. Different letters indicate significant differences $(p<0.05)$ between the mean values of sugar intake (lowercase letters), fermentation efficiency as percentage of the theoretical amount (capital letters) and fermentation yield from $100 \mathrm{~kg}$ of starch (bold capital letters). 1 Unmalted rye (Dańkowskie

is explained by the higher contents of FAN in barley malt [55].

In our research, the highest concentration of ethanol $(8.40 \pm 0.25) \%$ vol. was found in the mash containing $50 \%$ rye malt, while the lowest $(6.60 \pm 0.12) \%$ vol. in the mash containing $50 \%$ barley malt (Table 2 ).

As regards the residual sugars, the mash prepared exclusively from unmalted rye was marked after fermentation by the lowest content of reducing sugars and dextrins. However, it should be noted that the above mash was also characterized by the lowest content of sugar before fermentation. The decrease in dextrins content can be attributed to the continuous combined action of $\alpha$-amylase, $\beta$-amylase, and limit dextrinase. The activity of $\alpha$-amylase results in an increase in (shorter) dextrins; while $\beta$-amylase rapidly removes a maltose moiety from the non-reducing end of all dextrins. If the concerted activity of malt $\alpha$ - and $\beta$-amylases was sufficiently random, then it could be expected that this would result in a general decrease in the concentration of dextrins [56].

The highest amounts of non-hydrolyzed dextrins, between $(12.6 \pm 0.5)$ and $(14.7 \pm 0.6) \mathrm{g} \mathrm{L}^{-1}$, remained in the mashes containing $30 \%$ barley malt and $30 \%$ rye malt, respectively. The relatively low barley malt $\beta$-amylase activity (Table 1) could be the probable cause of incomplete starch hydrolysis and low ethanol production in the mash prepared with this malt. In turn, the high concentration of unhydrolyzed dextrins in the mash containing $30 \%$ rye malt could be a consequence of too high content of starch relative to the amylolytic activities present in the applied dose of the malt.
Diament cultivar). 2 Unmalted rye (70 \%) and wheat malt (30\%). 3 Unmalted rye $(70 \%)$ and rye malt $(30 \%) .4$ Unmalted rye $(70 \%)$ and barley malt $(30 \%) .5$ Unmalted rye $(50 \%)$ and wheat malt $(50 \%) .6$ Unmalted rye $(50 \%)$ and rye malt $(50 \%) .7$ Unmalted rye $(50 \%)$ and barley malt (50\%)

At higher malt dosages, malt provides a rich source of $\alpha$-amylase, and it has a greater effect than $\beta$-amylase does, thus resulting in lower levels of maltose and higher levels of glucose and maltotriose. It is clear that the addition of malted cereals leads to higher levels of soluble sugars and also that the addition of unmalted cereals brings in a certain level of carbohydrate. It is also important to consider the hydrolytic effects, which the endogenous malt starchdegrading enzymes bring into the system [57].

In order to evaluate fermentation results, the degree of sugar utilization and the efficiency of ethanol biosynthesis (expressed as percent of the theoretical amount) were calculated (Fig. 1). The highest sugar consumption rate $(94.19 \pm 2.35) \%$ was found for the mash prepared only from unmalted rye and treated with amylolytic preparations. In the mashes prepared from unmalted rye with the addition of cereal malts, sugar consumption ranged from $(83.74 \pm 2.09) \%$ for the mash containing $30 \%$ barley malt to $(93.08 \pm 2.33) \%$ for the mash containing $50 \%$ rye malt. In turn, fermentation efficiency (real yield relative to the theoretical amount) ranged from $(75.39 \pm 1.88) \%$ for the mash consisting of $50 \%$ unmalted rye and $50 \%$ rye malt to $(87.92 \pm 2.19) \%$ for the mash consisting of $50 \%$ unmalted rye and $50 \%$ wheat malt. Higher ethanol yields were found for mashes prepared with wheat malt $(p<0.05)$, whereas the lowest yield was observed for mashes containing rye malt. A likely reason for this may be the fact that despite its high $\alpha$-amylase activity, rye malt often adversely affects the course of fermentation as it contains compounds that inhibit the yeast activity. Cereal grains contain various amounts of non-starch polysaccharides (NSPs), which are 
composed predominantly of arabinoxylans (pentosans), $\beta$-glucans, and cellulose [58]. The detrimental effect of soluble NSPs is mainly associated with their viscosity and physiological effects on the digestive medium. The content and type of NSPs differ among cereals. NSP content relative to dry matter is lower in wheat kernels $(11.4 \%)$ than in rye $(13.2 \%)$. Arabinoxylans (AX) are the predominant NSP in wheat (6-8 \%) and rye (8.9\%), while $\beta$-glucans are the predominant NSP in barley (7.6\%) [59]. Most of the arabinoxylans found in cereal grains are insoluble in water, but those not bounded to the cell walls, which can form highly viscous solutions and absorb an amount of water equivalent to about ten times their weight, are named as water-extractable AX (WEAX). These compounds are important for brewing purpose and agricultural distillates production. Soluble NSPs cause an increase in the viscosity of the medium, generally hampering the digestion process, whereas insoluble NSPs impede the access of endogenous enzymes to their substrates by physical entrapment [45, 60].

Summing up, the obtained results indicate that under the conditions set in our experiments ethanol yield from $100 \mathrm{~kg}$ of starch was between $(54.26 \pm 1.36) \mathrm{L} \mathrm{A}_{100}$ (for the mash containing $50 \%$ rye malt) and $(63.30 \pm 1.58) \mathrm{L} \mathrm{A}_{100}$ (for the mash containing $50 \%$ wheat malt) (Fig. 1).

\section{Chemical composition of the obtained distillates}

During the fermentation process, yeasts produce ethanol and carbon dioxide, which promote the synthesis of alcohols, esters, organic acids, and these compounds determine the flavor and aroma of the alcoholic beverages [61-63]. The pathways of synthesis, type and concentration of these compounds also depend on the microorganisms present during the fermentation process [64], the chemical composition of the raw materials, ratio of $\mathrm{C} / \mathrm{N}$, and the environmental conditions [65, 66].

A comparison of the chemical composition of the obtained distillates demonstrates a significant effect of the cereal malts used in the preparation of sweet mashes (Tables 3, 4).

The main volatile compounds occurring in alcoholic beverages are aldehydes-intermediates in two-step decarboxylation of alpha-keto acids to alcohols as well as indirect products during the synthesis and oxidation of alcohols. Aldehydes, which represent a rather widely described class of compounds, as aroma compounds are often noted to have a negative influence on the quality characteristics of spirits. The concentrations of carbonyl compounds in agricultural distillates depend on the quality of raw materials, their chemical composition, the conditions of technological processes and microbial contamination [67].
Acetaldehyde is the predominant aliphatic carbonyl compound contained in raw spirits. Among the produced distillates, the highest concentration of acetaldehyde at $(135.82 \pm 2.56) \mathrm{mg} \mathrm{L}^{-1}, 100 \%$ vol. alcohol was found in the distillate from unmalted rye $(p<0.05)$. A comparison of distillates from mashes containing 30 and $50 \%$ malts shows considerable variation in acetaldehyde concentrations. This could be due to the quality and type of malts used. In the case of raw spirits obtained from mashes containing wheat malt, the concentration of acetaldehyde tended to decrease when the content of that malt in sweet mashes was increased $(p<0.05)$. In contrast, distillates produced from mashes containing rye malt exhibited an inverse tendency. Of note is the distillate derived from the mash containing $50 \%$ unmalted rye and $50 \%$ wheat malt, which revealed the lowest acetaldehyde content at (36.06 \pm 0.35$) \mathrm{mg} \mathrm{L}^{-1} 100 \%$ vol. alcohol (Table 3).

Also, the presence of aldehydes such as furfural, hexanal, and benzaldehyde was determined in the studied distillates. Furfural is a compound formed during the dehydration of pentoses in technological processes carried out at elevated temperatures [68]. The lowest concentration of this aldehyde $(18.29 \pm 1.39) \mathrm{mg} \mathrm{L}^{-1} 100 \%$ vol. alcohol was found in the distillate derived from the mash containing unmalted rye only. A higher malt content in the mashes was reflected in an increase in the concentration of furfural in the obtained distillates. The highest concentration of this compound (117.23 \pm 0.80$) \mathrm{mg} \mathrm{L}^{-1} 100 \%$ vol. alcohol was found in the distillate from the mash containing $50 \%$ rye malt. The studied cereal distillates also contained small amounts of hexanal and benzaldehyde (Table 3).

Esters (mostly ethyl esters of monocarboxylic acids) are an important group of flavor compounds found in spirits such as whisky, cognac, and rum. Total ester content varies widely in strong spirits. Ethyl acetate is quantitatively the most important component of the ester fraction, usually accounting for over $50 \%$ of the total. Many short-chain esters, such as isobutyl acetate, ethyl 3-methylbutyrate, ethyl n-butyrate, 2-methylbutyl acetate, and 3-methylbutyl acetate, have fairly strong odors. Therefore, their occurrence in whisky, cognac, and rum has been investigated extensively [69]. In whisky, the concentration of long-chain carboxylic acid esters increases from ethyl hexanoate up to ethyl decanoate and then declines with $\mathrm{C} 18$ ethyl esters typically being the longest esters to be detected $[70,71]$.

Determination of the content of esters in the analyzed distillates shows that their concentrations were higher $(p<0.05)$ in distillates from mashes containing cereal malts than in raw spirits obtained from unmalted rye only. In this group of compounds, ethyl acetate is predominant. The highest concentrations of ethyl acetate were found in distillates from fermented mashes containing $50 \%$ unmalted rye and $50 \%$ rye malt (Table 3 ). 


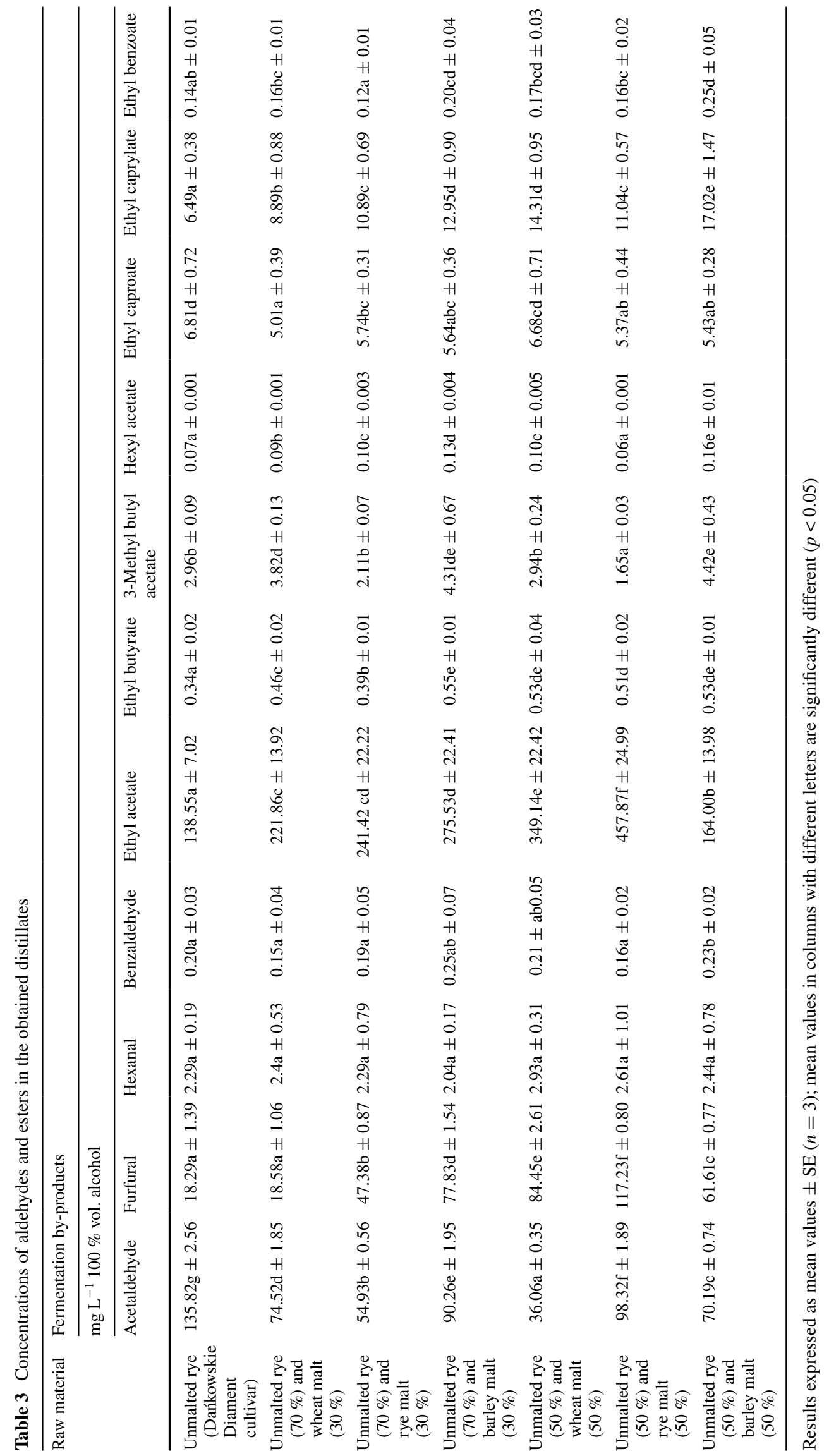




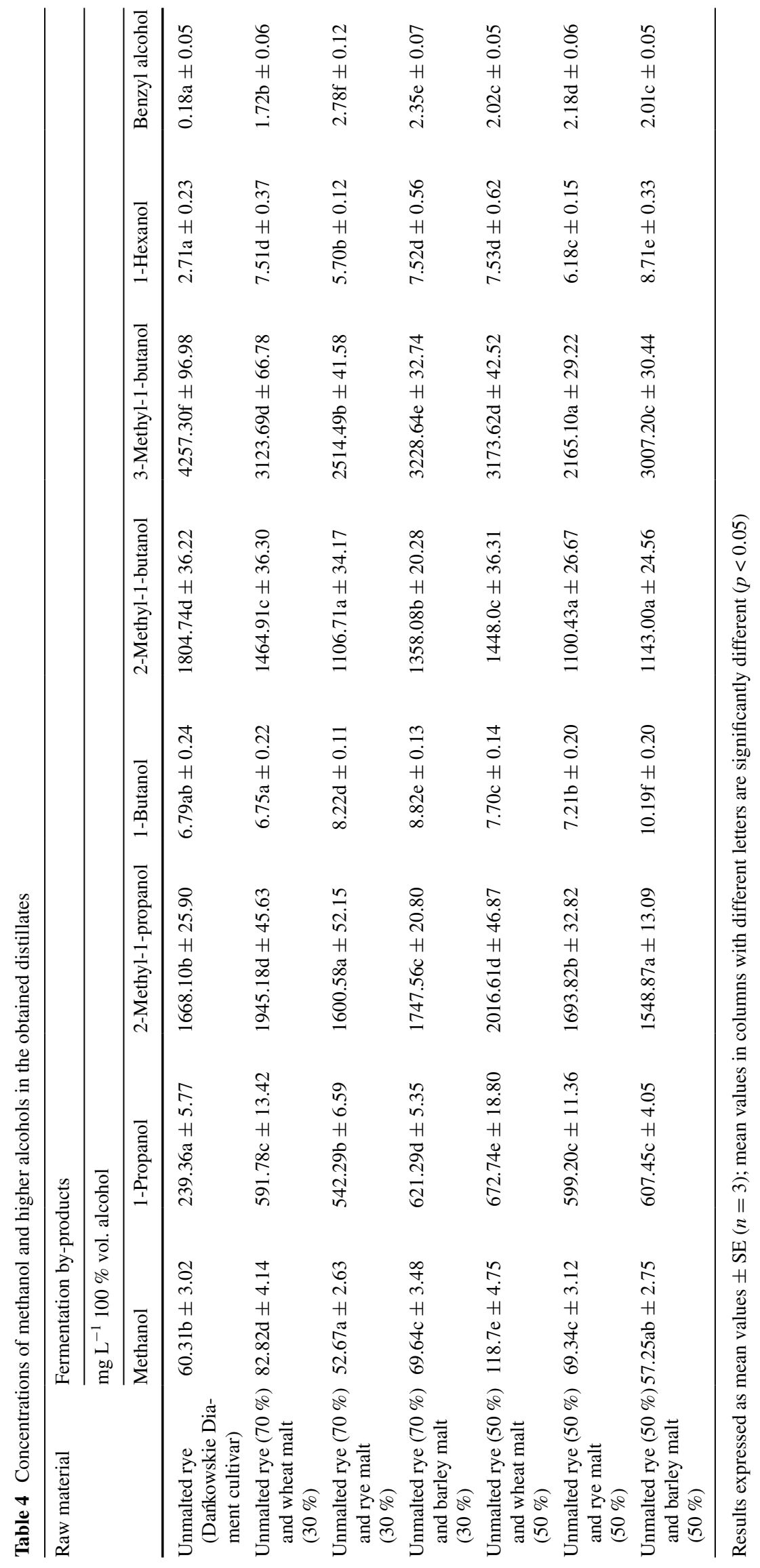


The tested distillates exhibited small amounts of esters of higher carboxylic acids and ethanol, i.e., ethyl caproate (ethyl hexanoate) and ethyl caprylate (ethyl octanoate) as compared to the predominant ethyl acetate. In the distillate obtained from unmalted rye, the concentration of those esters was similar $(p>0.05)$. In the majority of spirit distillates obtained from mashes containing cereal malts, the concentrations of ethyl caproate were lower than in control (the distillate obtained from unmalted rye only), $(p<0.05)$. On the other hand, a higher content of wheat and barley malts in mashes led to an increase in the concentration of ethyl caprylate in the distillates. Trace amounts of hexyl acetate were also found in all raw spirit samples (Table 3).

One of the undesirable compounds in spirit distillates is methanol, which is generated through hydrolysis of methylated pectins present in the plants and fruits. Methanol will be an unavoidable component of fermented mashes from fruits with high pectin contents such as Williams pears, plums, and mirabelles. This compound is produced in the process of hydrolysis of pectins by specific pectolytic enzymes, and in particular pectin methylesterase [72]. While methanol does not directly affect the flavor of the distillate, it is subjected to restrictive controls owing to its high toxicity [73]. Nevertheless, due to the fact that methanol arises as a result of de-esterification of pectins, which are naturally present in fruits, its presence at limited concentrations in fruit-derived distillates proves the identity of those products [74]. Small pectic deposits have been reported in barley coleoptiles [75] and in wheat grain [76]. It is also believed that some yeast strains (among others assigned to the genus Saccharomyces) have pectin methyl esterases [77, 78].

Based on the literature data [6], methanol concentrations for different samples of Scotch whiskies (single malt, single grain, blended) ranged between 4.7 and $16.4 \mathrm{~g}$ per $100 \mathrm{~L}$ absolute alcohol (i.e., between $47 \mathrm{mg}$ and $164 \mathrm{mg} \mathrm{L}^{-1}$ ).

EU Regulation no. 110/2008 [79] defines acceptable concentrations of methanol in ethyl alcohols of agricultural origin, wine spirits, and fruit spirits, but does not set any limits on the content of this compound in distillates of agricultural origin and grain spirits. Methanol concentrations in the obtained distillates (raw spirits) varied widely $(p<0.05)$ between $(52.67 \pm 2.63) \mathrm{mg} \mathrm{L}^{-1} 100 \%$ vol. alcohol (70 \% unmalted rye and $30 \%$ rye malt) and $(118.7 \pm 4.75) \mathrm{mg} \mathrm{L}^{-1} 100 \%$ vol. alcohol (50\% unmalted rye and $50 \%$ wheat malt). The greatest differences $(p<0.05)$ in the concentration of methanol, as compared to the control (the distillate obtained from unmalted rye only), were noted in distillates from fermented mashes containing wheat malt (especially at a concentration of $50 \%$ ), (Table 4). It should, however, be noted that all obtained distillates meet the requirements of the mentioned EU Regulation [79], which stipulates that the maximum methanol content in ethyl alcohol of agricultural origin shall amount to $30 \mathrm{~g} \mathrm{hL}^{-1} 100 \%$ vol. alcohol (i.e., $300 \mathrm{mg} \mathrm{L}^{-1}$ ).

From a quantitative point of view, the most important group of fermentation by-products is higher alcohols, represented mainly by: n-propanol, amyl alcohol, and its isomers, i.e., 2-methyl-1-butanol, 3-methyl-1-butanol. The regulation of the biosynthesis of higher alcohols is complex, since they may be produced as by-products of amino acid catabolism or via pyruvate derived from carbohydrate metabolism [44]. These compounds play an important role in the formation of flavor qualities in spirits, such as whisky and Starka. Scotch malt whiskies are rich in higher alcohols, with contents often well over $2 \mathrm{~g} \mathrm{~L}^{-1}$ [9]. According to the recommendations of the Polish Standard [80], the maximum concentration of these compounds in the agricultural distillates used for Starka production is $5 \mathrm{~g} \mathrm{~L}^{-1} 100 \%$ vol. alcohol.

Aylott and MacKenzie [6] carried out research aimed at developing of analytical strategies to confirm the authenticity of Scotch whisky. Blended Scotch whiskies, being combinations of many different Scotch malts and grains, are diverse and show representative analytical profiles of their constituent parts. The concentrations of 2- and 3-methyl butanol in Grain Scotch whisky were relatively low compared to n-propanol and isobutanol. The Malt Scotch whiskies were rich in these higher alcohols, with the average 2- and 3-methyl butanol concentration being $190 \mathrm{~g} / 100 \mathrm{~L}$ absolute alcohol, compared to only $30 \mathrm{~g} / 100 \mathrm{~L}$ absolute alcohol in the Grain Scotch whiskies.

In the obtained distillates, the most abundant among higher alcohols was 3-methyl-1-butanol. In the trials obtained from unmalted rye, it was followed by 2-methyl1-butanol and 2-methyl-1-propanol, while the distillates from mashes containing cereal malts exhibited higher concentrations of 2-methyl-1-propanol than 2-methyl-1-butanol (Table 4).

The highest concentrations of amyl alcohol isomers (i.e., 2-methyl-1-butanol and 3-methyl 1-butanol) were found in the distillate obtained from unmalted rye mash. In turn, distillates originating from fermented mashes containing cereal malts exhibited higher concentrations of 1-propanol, 1-butanol, 1-hexanol, and benzyl alcohol $(p<0.05)$. The differences found in higher alcohol concentrations in the tested distillates are probably the consequence of the type of raw material. This is confirmed by report by Kłosowski et al. [81], who studied influence of various yeast strains and selected starchy raw materials on production of higher alcohols during the alcoholic fermentation process. The authors observed that among the distillates obtained from different raw materials, the highest final total content of higher alcohols (ca. $5.46 \mathrm{mg} \mathrm{L}^{-1} 100 \%$ vol. alcohol, on average) was found in the distillates produced from the maize mashes, while in the rye and amaranth distillates 
the concentrations of these compounds were similar and reached the level of ca. $3.44 \mathrm{mg} \mathrm{L}^{-1} 100 \%$ vol. alcohol.

\section{Conclusions}

Presented study examined the efficiency of rye starch hydrolysis in a mashing process using either enzymatic preparations or cereal malts as a source of amylolytic enzymes and starch. Also, the effects of those ingredients on the results of fermentation and the composition of the distillates were investigated.

The results obtained indicate the possibility to use all tested in our study types of malts in the manufacturing of agricultural distillates. The concentration of fermentable sugars was twofold higher in sweet mashes containing $30 \%$ cereal malts in comparison with the rye mash prepared with amylolytic preparations. The highest efficiency of process, comparable to the obtained in the rye mash digested with amylolytic preparations, was reached after fermentation of the mash prepared with $50 \%$ wheat malt. The fermentation of mash containing $50 \%$ unmalted rye grain and $50 \%$ brown barley malt by the low $\beta$-amylase activity resulted in the lowest ethanol concentration and relatively high amount of non-hydrolyzed dextrins in the mash after fermentation. To improve fermentation efficiency of distillery mashes with the application of brown malts, such as used in our study barley malt exhibiting a reduced amylolytic activity, further investigations concerning the mashing with these malts are justified.

The spirit distillates originating from mashes containing cereal malts were characterized by lower concentrations of undesirable acetaldehyde than the distillate obtained from unmalted rye alone. Moreover, methanol content in all the obtained distillates meets the requirements included in the Regulation (EC) No 110/2008.

In summary, taking into account an increased care and attention to niche products [23], cereal malts can be valuable raw materials for the micro-distilleries, ensuring an appropriate starch saccharification and efficient fermentation, as well as leading to original distillates, which may be used for the production of spirits with an interesting flavor profile. The production of distillates from malted and unmalted cereals may be incorporated in the manufacturing portfolio of agricultural distilleries to help increase their competitiveness and facilitate attracting new customers interested in original distillates.

Acknowledgments This work was supported by Polish National Centre for Research and Development under Grant PBS2/B8/9/2013.

\section{Compliance with ethical standards}

Conflict of interest None.
Compliance with ethics requirements This article does not contain any studies with human or animal subjects.

Open Access This article is distributed under the terms of the Creative Commons Attribution 4.0 International License (http://creativecommons.org/licenses/by/4.0/), which permits unrestricted use, distribution, and reproduction in any medium, provided you give appropriate credit to the original author(s) and the source, provide a link to the Creative Commons license, and indicate if changes were made.

\section{References}

1. WHO Global Status Report on Alcohol (2004) Department of Mental Health and Substance Abuse Geneva. ISBN 924156272 2

2. Serna-Saldivar SO (2010) Production of malts, beer, alcohol spirit and fuel ethanol. In: Serna-Saldivar SO (ed) Cereal grain. Properties, processing and nutritional attributes. Taylor \& Francis Group, Boca Raton

3. Gupta M, Abu-Ghannam N, Gallaghar E (2010) Barley for brewing. Characteristic changes during malting, brewing and applications of its by-products. Compr Rev Food Sci F 9:318-328

4. The Royal Commission On Whisky And Other Potable Spirits (1909) British Medic J 2:399-404

5. Russell I, Stewart G, Bamforth C (2003) Whisky. Technology, production and marketing, 1st edn. Elsevier Ltd, London

6. Aylott RI, MacKenzie WM (2010) Analytical strategies to confirm the generic authenticity of Scotch whisky. J Inst Brew 116:215-229

7. MacKenzie WM, Aylott RI (2004) Analytical strategies to confirm Scotch whisky authenticity. Part II: mobile brand authentication. Analyst 129:607-612

8. Bringhurst A (2015) 125th Anniversary review: barley research in relation to Scotch whisky production. J Inst Brew 121:1-18

9. Lyons TP (2003) In: Jacques KA, Lyons TP, Kelsall DR (eds) The alcohol textbook, 4 th edn. Nottingham, UK

10. Brown JH (1990) In: Campbell I (ed) Proceedings of the third aviemore conference on malting brewing and distilling. Institute of Brewing, London

11. Walker EW (1986) In: Campbell I, Priest FG (eds) Proceedings of the second Aviemore conference on malting, brewing and distilling. Institute of Brewing, London

12. Brosnan JM, Makari S, Paterson L, Cochrane MP (1999) In: Campbell I (ed) Proceedings of the fifth Aveimore conference on malting, brewing and distilling. Institute of Brewing, London

13. Swanston JS, Newton AC, Brosnan JM, Fotheringham A, Glasgow E (2005) Determining the spirit yield of wheat varieties and variety mixtures. J Cereal Sci 42:127-134

14. Haln RR (1966) Sorghum as a brewing adjunct. Brewer's Dig 49:70-74

15. Rami JF, Dufour P, Trouche G, Fliedel G, Mestres C, Davries F, Blanchard P, Hamon P (1998) Quantitative trait loci for grain quality, productivity, morphological and agronomical traits in sorghum (Sorghum bicolor L. Moench). Theor Appl Genet 97:605-616

16. Zheng XW, Tabrizi MR, Nout MJR, Han BZ (2011) DaquA traditional Chinese liquor fermentation starter. J Inst Brew 117:82-90

17. http://spirits.eu. Accessed 5 Sept 2015

18. Regulation (EC) No 110/2008 of the European Parliament and of the Council of 15 January 2008 on the definition, description, presentation, labelling and the protection of geographical 
indications of spirit drinks and repealing Council Regulation (EEC) No 1576/89. Off J Eur Union L 39/16 (2008)

19. http://www.berlinerbrandstifter.com/en/kornbrand/. Accessed 23 July 2015

20. Arendt EK, Zannini E (2013) Cereal grains for the food and beverage industries. Woodhead Publishing Series in Food Science, Technology and Nutrition: Number 248 Woodhead Publishing Limited, Oxford Cambridge, Philadelphia

21. Kłosowski G, Mikulski D, Czupryński B, Kotarska K (2010) Characterisation of fermentation of high-gravity maize mashes with the application of pullulanase, proteolytic enzymes and enzymes degrading non-starch polysaccharides. J Biosci Bioeng 109:466-471

22. Poel P, Gosepa S, Kroes W, Kruis G, Berkhout B, de Wit W (2010) The contribution of the spirits industry to the EU economy. A report commissioned by The European Spirits Companies Liaison Group in coordination with The European Spirits Organisation-CEPS and conducted by Ernst \& Young Tax Advisors and Regioplan Policy Research, Amsterdam

23. Best A (2009) International study of the value adding of regional produce through the manufacture and distillation of spirits by micro-distilleries. The Pratt Foundation/ISS Institute Overseas Fellowship, Melbourne

24. Aromatische Malze und Malzextrakte für die Spirituosenindustrie (2014) Weyermann Specialty Malting Company, http://www. Weyermann.de. Accessed 20 Sept 2014

25. Balcerek M, Pielech-Przybylska K (2009) Effect of supportive enzymes on chemical composition and viscosity of rye mashes obtained by PSL method and efficiency of their fermentation. Eur Food Res Technol 229:141-151

26. AOAC (1995) Official Methods of Analysis of AOAC International, 16th edn. Methods: 925.10, 945.09, 957.03, 960.52, AOAC International, Maryland

27. Pomeranz Y, Meloan CE (1994) Food analysis. Theory and practice. Part III. Carbohydrates. Aspen Publishers, Maryland

28. BS EN ISO 10520:1998. Native starch. Determination of starch content. Ewers polarimetric method, ISBN: 0580303950

29. ICC (1998). Standard methods: simple and specific assay for alphaamylase, beta-amylase, and beta-glucanase. no. 303. Vienna: ICC. https://www.icc.or.at/standard_methods. Accessed 05 Sept 2015

30. Alpha-amylase assay procedure (2012) (Ceralpha Method) K-Cera 01/12 for the measurement of plant and microbial alphaamylases. Megazyme International Wicklow, Ireland

31. Beta-amylase assay procedure (2010) (Betamyl-3 Method) K-Beta3 10/10. Megazyme International Wicklow, Ireland

32. Koehler P, Wieser H (2013) In: Gobbetti M, Gänzle M (eds) Handbook on sourdough biotechnology. Springer Science \& Business Media, New York

33. Clancy JA, Tillman BA, Pan WL, Ullrich SE (1991) Nitrogen effects on yield and malting quality of barley genotypes under no-till. Agron J 83:341-346

34. Eagles HA, Bedggood AG, Panozzo JF, Martin PJ (1995) Cultivar and environmental effects on malting quality in barley. Aust $\mathrm{J}$ Agric Res 46:831-844

35. Garstang JR, Giltrap NJ (1990) The effect of applied and soil mineral nitrogen on yield and quality of malting barley varieties. Asp Appl Biol 25:315-327

36. Zembold-Guła A, Błażewicz J, Liszewski M (2010) Malting time of brewing barley grain as a factor modifying the quality of pilsner type malt. J Cent Eur Agric 10:341-346

37. Blömelhuber G (2012) Cereals, malts and hops. Brauwelt Int 2:75-83

38. Pietruszka M, Szopa J St (2014) Agricultural distillates from Polish varieties of rye. Czech J Food Sci 32:406-411
39. Dewar J, Taylor JRN, Berjak P (1997) Determination of improved steeping conditions for sorghum malting. J Cereal Sci 26:129-136

40. Jin YH, Du JHD, Zhang KL, Zhang XC (2011) Effects of wheat starch contents on malt qualities. J Inst Brew 117:534-540

41. Kunachowicz H, Nadolna I, Iwanow K, Przygoda B, Szwed Ł, Błażewicz J, Zembold-Guła A, Pelak M, Dawidowicz A (2009) Effect of malting time and fractionation of barley grain on malt Kolbach Index and content of free amino nitrogen in worts. Food Sci Technol Qual 6:119-128

42. Fox GP, Onley-Watson K, Osman A (2002) Multiple linear regression calibrations for barley and malt protein based on the spectra of hordein. J Inst Brew 108:155-159

43. Moll M (1979) In: Pollock JRA (ed) Brewing science. Academic Press, London

44. Russell I (2003) Understanding yeast fundamentals. In: Jacques KA, Lyons TP, Kelsall DR (eds) The alcohol textbook, 4th edn. Nottingham University, Nottingham

45. Hübner F, Schehl BD, Gebruers K, Courtin CM, Delcour JA, Arendt EK (2010) Influence of germination time and temperature on the properties of rye malt and rye malt based worts. J Cereal Sci 52:72-79

46. Albers E, Larsson C, Lidén G, Niklasso Gustafsson L (1996) Influence of the nitrogen source on Saccharomyces cerevisiae anaerobic growth and product formation. Appl Environ Microbiol 62:3187-3195

47. Lekkas C, Hill AE, Taidi B, Hodgson J, Stewart GG (2009) The role of small wort peptides in brewing fermentations. J Inst Brew 115:134-139

48. Olofsson K, Bertilsson M, Lidén G (2008) Short review on $\mathrm{SSF}$-an interesting process option for ethanol production from lignocellulosic feedstocks. Biotechnol Biofuels 1:7. doi:10.1186/1754-6834-1-7

49. Ingledew WM (2003) In: Jacques KA, Lyons TP, Kelsall DR (eds) The alcohol textbook, 4th edn. Nottingham, UK

50. Manners DJ (1985) Some aspects of the metabolism of starch. Cereal Foods World 30:722-727

51. Montanari L, Floridi S, Marconi O, Tironzelli M, Fantozzi P (2005) Effect of mashing procedures on brewing. Eur Food Res Technol 221:175-179

52. Whitehurst RJ, van Oort M (2010) Enzymes in food technology, 2nd edn. Wiley-Blackwell, Iowa

53. Kristiansen AG, Johansen KL (2011) 2020: the future brewerypart 1. Brauwelt Int 2:88-92

54. Kotarska K, Czupryński B, Kłosowski G (2006) Effect of various activators on the course of alcoholic fermentation. J Food Eng 77:965-971

55. Back W (2005) Ausgewählte Kapitel der Brauereitechnologie, 1st edn. Fachverlag Hans Carl, Nürnberg

56. Vriesekoop F, Rathband A, MacKinlay J, Bryce JH (2010) The evolution of dextrins during the mashing and fermentation of allmalt whisky production. J Inst Brew 116:230-238

57. Goode DL, Wijngaard HH, Arendt EK (2005) Mashing with unmalted barley-impact of malted barley and commercial enzyme (Bacillus spp.). MBAA TQ 42:184-198

58. Lineback DR, Rasper VF (1988) In: Pomeranz Y (ed) Wheat: chemistry and technology, vol 1. American Association of Cereal Chemists, St. Paul, Minnesota

59. Schweizer TF, Würsch P (1981) In: James WPT, Theander O (eds) The analysis of dietary fiber in food. Marcel Dekker Inc, New York

60. Bedford MR (1995) Mechanism of action and potential environmental benefits from the use of feed enzymes. Anim Feed Sci Technol 53:145-155 
61. Santillán V, García G (1998) Congeners biosynthesis during alcoholic fermentations. Rev Lat Am Microbiol 40:109-119

62. Díaz-Montaño DM, Délia ML, Estarrón EM, Strehaiano P (2008) Fermentative capability and aroma compound production by yeast strains isolated from Agave tequilana Weber juice. Enzyme Microb Technol 42:608-616

63. He Y, Dong J, Yin H, Zhao Y, Chen R, Wan X, Chen P, Hou X, Liu J, Chen L (2014) Wort composition and its impact on the flavour-active higher alcohol and ester formation of beer-a review. J Inst Brew 120:157-163

64. Escalante-Minakata P, Blaschek HP, Barba de la Rosa AP, Santos L, De León-Rodríguez A (2008) Identification of yeast and bacteria involved in the mezcal fermentation of Agave salmiana. Lett Appl Microbiol 46:626-630

65. Pinal L, Cedeño M, Gutiérrez H, Álvarez J (1997) Fermentation parameters influencing higher alcohol production in the tequila process. Biotechnol Lett 19:45-47

66. Santillán V, García G (1998) Congeners biosynthesis during alcoholic fermentations. Rev Lat Am Microbiol 40:109-119

67. Plutowska B, Biernacka P, Wardencki W (2010) Identification of volatile compounds in raw spirits of different organoleptic quality. J Inst Brew 116:433-439

68. Navarro AR (1994) Effects of furfural on ethanol fermentation by Saccharomyces cerevisiae: mathematical models. Curr Microbiol 29:87-90

69. Nykänen L, Suomalainen H (1983) In: Nykanen L, Suomalainen $\mathrm{H}$ (eds) Aroma of beer, wine and distilled alcoholic beverages. Reidel Publishing Company, Dordrecht

70. Suomalainen H, Nykanen L, Eriksson K (1974) Composition and consumption of alcoholic beverages-a review. Am J Enol Vitic 25:179-187

71. IARC (1988) Monographs on the evaluation of carcinogenic risk to humans. In: Alcohol drinking Part 3. Chemical composition of alcoholic beverages. Additives and contaminants. IARC, Lyon

72. Adam L, Versini G (1996) A study on the possibilities to lower the content of methyl-alcohol in eaux-de-vie de fruits.
Directorate-General XII Science, Research and Development EUR 16864 EN Published by the EUROPEAN COMMISSION Directorate-General XII Science, Research and Development B-1049 Brussels. ISBN 92-827-7208-X

73. Cabaroglu T, Yilmaztekin M (2011) Methanol and major volatile compounds of Turkish Raki and effect of distillate source. J Inst Brew 117:98-105

74. Nikićević N, Tešević V (2005) Possibilities for methanol content reduction in plum brandy. J Agric Sci 50:49-60

75. Gibeaut DM, Pauly M, Bacic A, Fincher GB (2005) Changes in cell wall polysaccharides in developing barley (Hordeum vulgare) coleoptiles. Planta 22:729-738

76. Chateigner-Boutin AL, Bouchet B, Alvarado C, Bakan B, Guillon $\mathrm{F}$ (2014) The wheat grain contains pectic domains exhibiting specific spatial and development-associated distribution. PLoS One 21;9(2):e89620. doi: 10.1371/journal.pone.0089620. http:// www.ncbi.nlm.nih.gov/pmc/articles/PMC3931795/. Accessed 10 Sept 2015

77. Gainvors A, Karam N, Lequart C, Belarbi A (1994) Use of Saccharomyces cerevisiae for the clarification of fruit juices. Biotechnol Lett 16:1329-1334

78. Arrizon J, Gschaedler A (2007) Effects of the addition of different nitrogen sources in the tequila fermentation process at high sugar concentration. J Appl Microbiol 102:1123-1131

79. Regulation (EC) No 110/2008 of the European Parliament and of the Council of 15 January 2008 on the definition, description, presentation, labelling and the protection of geographical indications of spirit drinks and repealing Council Regulation (EEC) No 1576/89. Off J Eur Union L 39/16 (2008)

80. Polish Standard (2007) PN-A-79528-2 Agricultural distillate and agricultural ethyl alcohol (in Polish)

81. Kłosowski G, Mikulski D, Macko D, Miklaszewska B, Kotarska K, Czupryński B (2015) Influence of various yeast strains and selected starchy raw materials on production of higher alcohols during the alcoholic fermentation process. Eur Food Res Technol 240:233-242. doi:10.1007/s00217-014-2323-8 